\title{
INNOVATIVE MANAGEMENT OF ANAL FISTULA: PARTIAL FISTULECTOMY WITH KSHARSUTRA (HIGH ANAL / HORSE SHOE FISTULA)
}

\author{
RATHOD A. ${ }^{*}$, REDDY K. ${ }^{2}$, PADAVI D. ${ }^{1}$, MAHADIK R. ${ }^{1}$ AND YADAV M. ${ }^{1}$ \\ 1 Padmashree Dr. D.Y. Patil College of Ayurved \& Research Institute, Nerul, Navi Mumbai- 400 706, MS, India. \\ 2R.A. Podar Govt. Ayurved Medical College, Worli, Mumbai- 400 018, MS, India. \\ ${ }^{*}$ Corresponding Author: Email- dramarrathod@yahoo.com
}

Received: April 12, 2013; Accepted: April 25, 2013

\begin{abstract}
-
Aim and Objective- Anal fistula is a condition which has been recognized as a difficult surgical disease in all the ancient [1] and modern medical sciences of the world. The approach to the treatment for a single disease is only suggestive of the fact that none of these methods is satisfactory. 'Ksharsutra' is being used successfully in the management of anal fistula [2], but in the case of High Anal / Horse Shoe Fistula particularly it is not convenient as size of wound is big which increases duration of therapy and hospitalization and ultimately on cost of therapy. To overcome all these problems, partial fistulectomy with 'Ksharsutra' is the ray of Hope.

Material and Methods- Patients are recruited from Shalyatantra OPD after confirmed diagnosis. Ethical guidelines of ICMR for human research were strictly followed.

Results and Discussion- All Patients were diagnosed, investigated and after physical fitness under spinal anesthesia, Partial Fistulectomy with 'Ksharsutra' was carried out. 'Ksharsutra' was changed on weekly basis \& patients were observed for parameters during this weekly follow-up for 12 weeks. All observations were recorded in the Case record Form. All study data was analyzed by applying Students Paired't' test and significance ' $P$ ' value calculated for individual symptoms.

Conclusion- High anal fistula with partial fistulectomy 'Ksharsutra' is an ideal treatment because recovery of disease is fast \& none of expected complication like incontinence of sphincter control, fecal soiling, rectal prolapse were found \& recurrence rate is only $3-4 \%$. So this therapy is effective, has less complications with minimal récurrence rate.

Keywords- anal fistula, fistulectomy, bhagandar, Ksharsutra therapy
\end{abstract}

Citation: Rathod A., et al. (2013) Innovative Management of Anal Fistula: Partial Fistulectomy with Ksharsutra (High Anal / Horse Shoe Fistula). International Journal of Medical and Clinical Research, ISSN: 0976-5530 \& E-ISSN: 0976-5549, Volume 4, Issue 1, pp.-252-257.

Copyright: Copyright@2013 Rathod A., et al. This is an open-access article distributed under the terms of the Creative Commons Attribution License, which permits unrestricted use, distribution and reproduction in any medium, provided the original author and source are credited.

\section{Introduction}

Ayurveda is the most ancient health care system and is widely practiced in India. Whole globe is looking for innovative treatment through Ayurveda for diseases like high anal fistula / horse shoe fistula etc, as on today complete eradication by any modality will be miracle. Anal fistula is a condition which has a complicated pathoetiology described in all the ancient [1] and modern medical sciences. The prevalence rate of anal fistula is 8.6 cases per 100,000 populations [3]. It has categorized as a surgical condition and almost all the surgeons from the era of 'Sushruta' (1500 BC) to Hippocrates $(450 \mathrm{BC})$ and down the line modern medical science has realized the challenges. Surgical, medical or medico-surgical treatment with scientific description of fistula is given in "Sushrut Samhita - A textbook of Ancient Indian Surgery" written about 1000 BC by Sushruta - The Father of Surgery [4]
ते तु भगगुदबस्तिपदेशदारणाच भगन्दरा इत्युच्यन्ते / अपक्व पिइका पक्वास्तु भगन्दरा //

तेषान्तु पूर्वरूपाणि कटीकपाल बेढना कण्डुदाहः शोफश्च
गुदख्य भवति / सु. नि. $\gamma / \beta$ 'Bhagandara' is a disease which causes splitting or discontinuity in the region of 'Bhaga', 'Vasti' (Perineal) and 'Guda'(Perianal) region. Approach to the treatment for a single disease in Ayurveda as well as in other science of medicine only suggestive of the fact that none of these methods is complete or satisfactory. The results of these operations also varied from surgeon to surgeon started concentrating on cutting short the duration of treatment since both 'fistulotomy' and 'fistulectomy' [5] involved a long period of post-operative dressings of the wound and consequently a prolonged hospitalization. In deeper fistula it did not prove its worth with the average surgeons because the primary closure of the wound often resulted in collection of the tissue fluid inside giving rise to a secondary abscess formation and recurrence of fistula. High anal and anal-rectal varieties still posed problems and the recurrence rate remained as high as $40-80$ percent even in the skilled hands $[6,7]$. And this surgical 
management carries several complications like frequent damage to the sphincter muscle resulting in incontinence of sphincter control, fecal soiling, rectal prolapse, anal stenosis, delayed wound healing and even after complete excision of tract there are the chances of subsequent recurrence. Hence this disease having still ray of hope and Ayurveda could be solution.

Acharya 'Sushruta' has described a detailed surgical approach involving excision of the fistulous tract but also felt the necessity of a para-surgical approach ('Ksharsutra')since he was not quite satisfied with the surgical excision which often resulted into recurrence. 'Ksharsutra' is a Sanskrit phrase in which Kshara refers to anything that is corrosive or caustic; while Sutra means a yarn or thread (The origin of the English word "Sew"). The Indian Council of Medical Research (ICMR) has validated this unique and effective approach. No doubt the standard ' Ksharsutra' is being used successfully in the management of anal fistula [2], but in the case of high anal/ Horse shoe fistula particularly it is not convenient as duration of therapy, increases hospitalization \& cost effectivity, discomfortness for prolonged duration during treatment to overcome all this problems partial fistulectomy with 'Ksharsutra' is radical cure specially for high anal/Horse shoe fistula. Considering the above mentioned view and the results of previous research on 'Ksharsutra' in the Shalyatantra (Surgery) department of Dr. D Y Patil College of Ayurveda, Hospital \& Research Institute, Nerul, Navi Mumbai were found to be very effective in the management of anal fistula. So it was decided to do further study on anal fistula (high anal / Horse shoe fistula) by partial fistulectomy with 'Ksharsutra'.

\section{Aims and Objective}

In present study efficacy of partial fistulectomy with 'Ksharsutra' in anal fistula (high anal / horse shoe fistula) were evaluated which also reviews ancient and current literature from Ayurveda as well as modern medicine.

This study also undertaken the standardization of partial fistulectomy with 'Ksharsutra 'therapy in anal fistula (high anal / Horse shoe fistula).

In this study adverse effect of partial fistulectomy with 'Ksharsutra' therapy, cutting and healing rate of fistulous tract, change in size of wound, discharge, slough, granulation tissue of \& development etc were the prime loci's as far as patients health concern.

\section{Material and Methods}

In present clinical study 30 patients of high anal / horse shoe anal fistula were selected randomly from 20 to 60 years age groups of both genders. Patient attending OPD at Department of Shalyatantra (Surgery) Dr. DY Patil Ayurvedic Hospital, Nerul, Navi Mumbai, were recruited after proper physical examination and investigations, if required, to conclude the final diagnosis. Ethical clearance was taken from Institutional Ethical Committee (IEC) of Dr. DY Patil College of Ayurveda and Hospital, Nerul, Navi Mumbai.

\section{Procedure}

Under spinal anesthesia with all aseptic precautions partial fistulectomy done and in remaining fistulous track 'Ksharsutra' was passed and tied snugly outside the anal orifice and left in situ (primary threading) [Fig-1]. One week later after assessing parameters, the old 'Ksharsutra' [Fig-2] was replaced by new one by railroad technique with gradual tightening of 'Ksharsutra. After replacement of the 'Ksharsutra', patient was advised to take luke warm water (about $110^{\circ} \mathrm{F}\left(43^{\circ} \mathrm{C}\right)$ ), 2-3 times/day for $15-20$ min or until the water cools down [4] after 'Ksharsutra' insertion and changing. during this therapy patient has advised to continue his normal routine work. The 'Ksharsutra' was changed weekly till it fell out spontaneously. During this study patients were observed for 12 weeks.

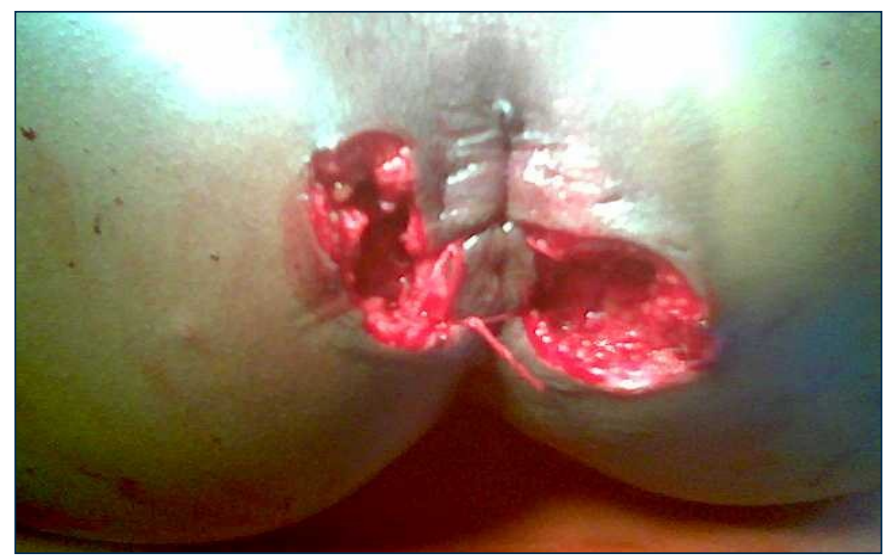

Fig. 1- Posterior Anal Horse shoe fistula Operative Day

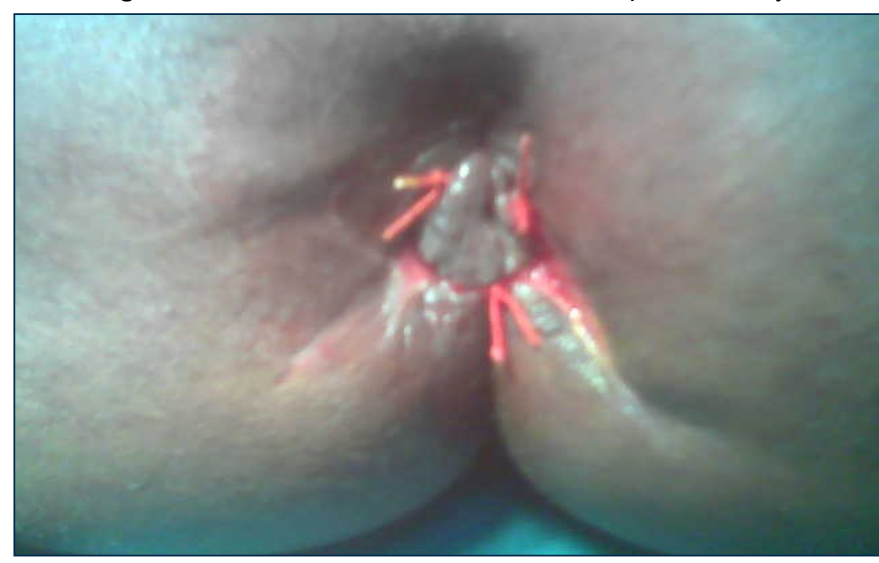

Fig. 2- 3rd Week Post-Operative

\section{Inclusive Criteria}

- Age between 20-60 years

- Irrespective of sex

- Established cases of anal fistula (high anal/Horse shoe fistula)

- Patient who is willing to undergo all informed procedures as per the clinical studies as per written consent.

\section{Exclusive Criteria}

- Prior involvement in other study.

- Pregnancy and lactation.

- Patient with known hypersensitivity to 'Ksharsutra'

- Age below 20 yr or above 60 yrs.

- latrogenic anal fistula.

- Recurrent anal fistula

- Patients who were suffering from anal fistula associated with Tuberculosis,

- Diabetes mellitus, Ulcerative colitis, Crohn's disease, Ca of rectum, AIDS, Hepatitis $B$, and Other systemic disorders diseases. Patient with malignancy/ Tuberculous anal fistula.

\section{Investigation}

All Investigations were done for pre-operative evaluation, to rule out 
the pathological conditions, physical fitness and for diagnosis of anal fistula and their tract.

Complete Heamogram (CBC), Erythrocyte Sedimentation Rate (ESR), Bleeding Time (BT), Blood Clotting Time(CT), Blood Sugarfasting \& post prandial, Renal function parameters ( BUN and serum Creatinine), HIV and other infectious markers were investigated. Chest X-Ray, Urograffin Fistulogram sensitivity test done for high anal, recurrent and previously operated cases, if necessary.

\section{Adjuvant therapy}

Hot sitz bath- Patients were instructed to take take luke warm water (about $110^{\circ} \mathrm{F}\left(43^{\circ} \mathrm{C}\right), 2-3$ times/day for $15-20 \mathrm{~min}$ or until the water cools down [8].

Laxative- Laxative (Gandarva Haritki Choorna about 3gm-oraly) was advised at bed time with luke warm water.

\section{Gradation and Observed Parameters}

[Table-1] showing Gradation and Observed Parameters

Table 1- Gradation and Observed Parameters

\begin{tabular}{|c|c|c|c|c|c|}
\hline Grade & Pain & Discharge & Burning sensation & Itching & Size of Wound \\
\hline 0 & No Pain & No discharge & No complain of burning sensation & No complain of itching & Healed wound \\
\hline 1. & $\begin{array}{l}\text { Negligible pain or Tolerable } \\
\text { pain (mild) }\end{array}$ & $\begin{array}{l}\text { Mild (If wound wets } 1 \mathrm{~cm} \times 1 \mathrm{~cm} \\
\text { gauze piece) }\end{array}$ & Negligible burning sensation & $\begin{array}{l}\text { Negligible itching, occa- } \\
\text { sional in a day }\end{array}$ & $\begin{array}{l}75 \% \text { Decreased of base } \\
\text { line size }\end{array}$ \\
\hline 2. & $\begin{array}{l}\text { Pain relieved by hot sits bath } \\
\text { (moderate) }\end{array}$ & $\begin{array}{l}\text { Moderate (If wound wets } 2 \mathrm{~cm} \mathrm{x} \\
2 \mathrm{~cm} \text { gauze piece) }\end{array}$ & $\begin{array}{l}\text { Occasional and tolerable burning sensation, relieved by } \\
\text { oleation }\end{array}$ & $\begin{array}{l}\text { Occasional itching, with } 4 \\
-6 \text { hours gap }\end{array}$ & $\begin{array}{l}450 \% \text { Decreased of base } \\
\text { line size }\end{array}$ \\
\hline 3. & $\begin{array}{l}\text { Pain relieved by oral analge- } \\
\text { sics (severe) }\end{array}$ & $\begin{array}{l}\text { Severe (If wound wets more } \\
\text { than } 2 \mathrm{~cm} \times 2 \mathrm{~cm} \text { gauze piece) }\end{array}$ & $\begin{array}{l}\text { Constant but tolerable burning sensation slightly re- } \\
\text { lieved by oleation }\end{array}$ & $\begin{array}{l}\text { Frequent itching, with } 2-3 \\
\text { hours gap }\end{array}$ & $\begin{array}{l}325 \% \text { Decreased of base } \\
\text { line size }\end{array}$ \\
\hline 4. & $\begin{array}{l}\text { Intolerable pain with sleep } \\
\text { disturbance (unbearable) }\end{array}$ & $\begin{array}{l}\text { Excruciating (Continuous and } \\
\text { profuse discharge) }\end{array}$ & $\begin{array}{l}\text { Intolerable burning sensation makes the patient uncom- } \\
\text { fortable and makes the patient to go for help }\end{array}$ & $\begin{array}{l}\text { Frequent \& continuous } \\
\text { itching sensation }\end{array}$ & $\begin{array}{l}\text { Base line (Operative day } \\
\text { time wound in } \mathrm{cm} \times \mathrm{cm} \text { ) }\end{array}$ \\
\hline
\end{tabular}

\section{Drug Profile}

\section{Thread}

For making of 'Ksharsutra', number 20 linen thread were used [2].

\section{2. 'Apamarga Kshar'}

Apamarga (Achyranthes aspera) has been described as a divine medicine in the vedas. 'Apamarga kshar' (alkali powder) [Fig-3] were prepared from Prickly Chaff-flower of Apamarga by standard Ayurvedic method of preparation. Pure 'Apamarga kshar' without adulteration were used for preparation of 'Ksharsutra'. The word Kshara is derived from the root Kshar, means to melt away or to perish. Acharya Sushruta defines as the material which destroys or cleans the excessive/the morbid doshas (Kshyaranat Kshyananat va Kshara) [4]. Achyranthes aspera showed various pharmacological activity like Anti-microbial [9,10], Anti inflammatory activity [11], Anti-carcinogenic activity, analgesic and antipyretic activity [12].

\section{Apamarga (Achyranthes aspera)}

Kingdom: Plantae

Order: Caryophyllales

Family: Amaranthaceae

Genus: Achyranthes

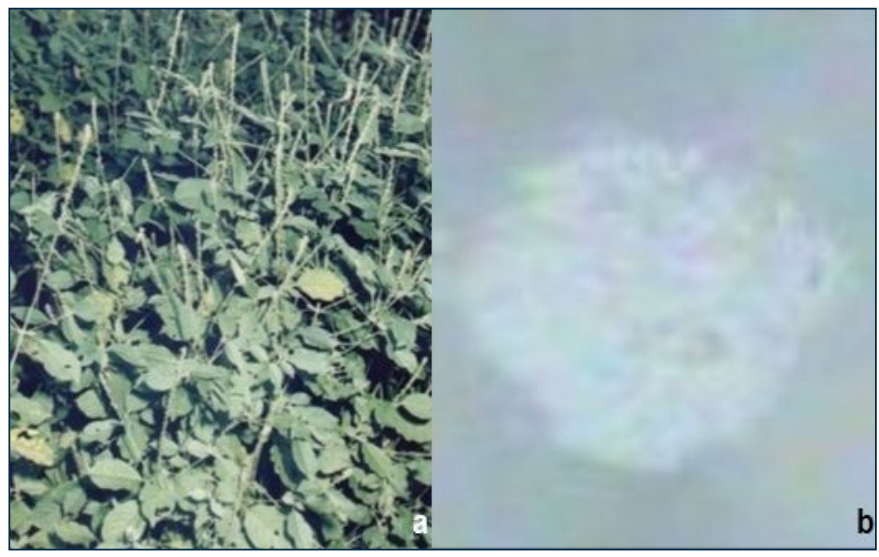

Fig. 3- Plant of Apamarga (a) and Apamarga Kshar (b)

\section{Ayurvedic Properties of 'kshar' \\ Guna (Quality): LaghuRruksha, Tikshna \\ Rasa (taste): Katu, Tikta \\ Vipak (Metabolism): Katu \\ Virya (Potency): Ushna}

\section{Snuhi Latex}

Euphorbia nerifolia L. Linn (Euphorbiaceae) is commonly occurs in the dry hilly rocky grounds of north, central and south India. Latex of 'snuhi' was collected by incising the stem of 'snuhi' plant and the secreted latex [Fig-4] were used for the preparation of 'Ksharsutra'. The aqueous extract of the latex of Euphorbia neriifolia facilitated the wound healing process as evidenced by increase in tensile strength, epithelization [13].

\section{Snuhi (Euphorbia nerifolia) \\ Familia: Euphorbiaceae \\ Subfamilia: Euphorbioideae \\ Tribus: Euphorbieae \\ Subtribus: Euphorbiinae \\ Genus: Euphorbia}

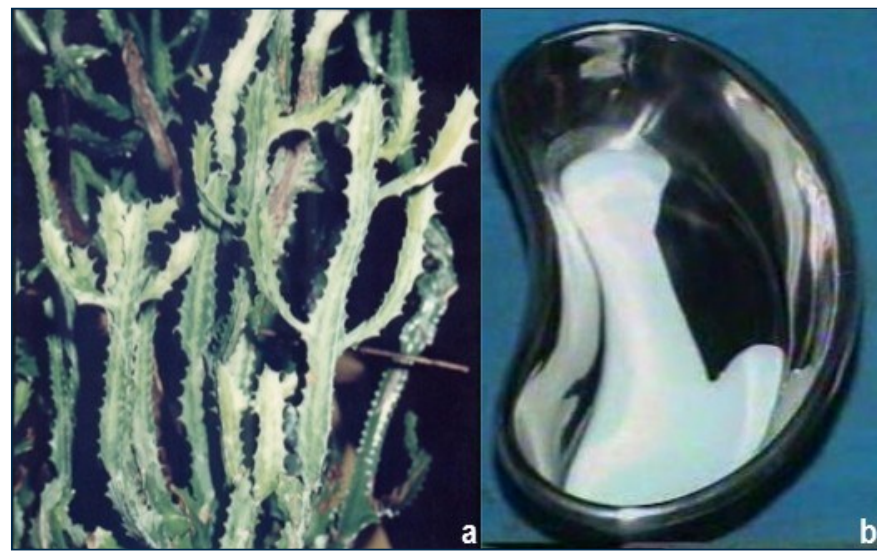

Fig. 4- Plant of Snuhi (a) Snuhi Latex (b) 


\section{Ayurvedic Properties of 'snuhi' Ksheer}

Guna (Quality): Laghu

Rasa (taste): Tikshan katu

Vipak (Metabolism): Katu

Virya (Potency): Ushan

Prabhav (Impact): Tikshanvirechan

\section{Haridra (Curcuma longa) Powder}

Species Curcuma longa dry rhizomes of 'Haridra' plant are cut into pieces \& make them powder [Fig-5] Seive this powder through a fine cloth the fine powder were used for the preparation of 'Ksharsutra'. It minimizes local reaction and Curcumin is also reported to have antibacterial, antiamoebic [14] and it also shows antitumour and anticarcinogenic [15] activities. The volatile oil of $C$. longa shows anti-inflammatory [16] antibacterial and antifungal activities [17].

\section{Haridra (Curcuma longa)}

Class: Liliopsida

$$
\begin{aligned}
& \text { Sub-class: Commelinids } \\
& \text { Order: Zingiberales } \\
& \text { Family: Zingiberaceae } \\
& \text { Genus: Curcuma }
\end{aligned}
$$

\section{Ayurvedic Properties of 'Haridra'}

Guna (Quality): Rruksa

Rasa (Taste): Tikta, katu

Vipak(Metabolism): Katu

Virya (Potency): Usna

Karma (Function): Krimighna, Vishagna, Varnya

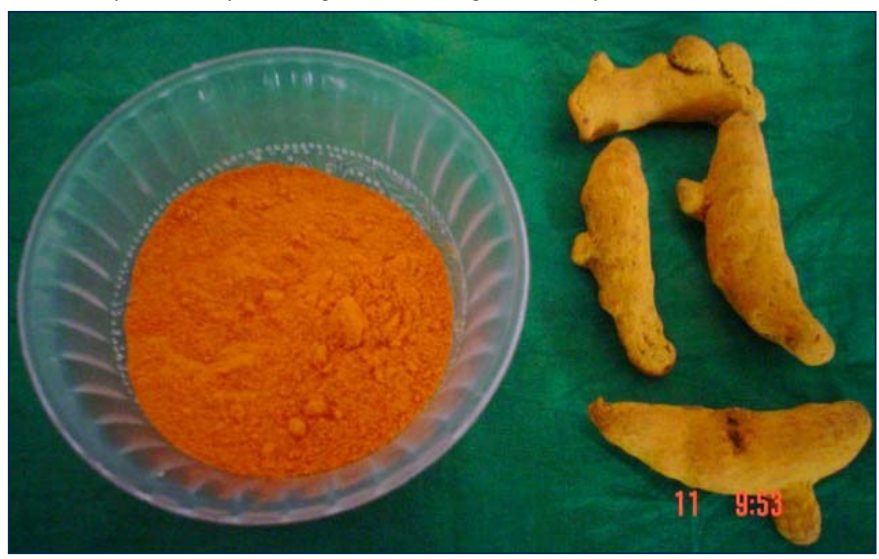

Fig. 5- Haridra [Curcuma longa] Powder

\section{Method of 'Ksharasutra' Preparation}

For the preparation of 'Ksharasutra' $4 \times 11 / 2 \times 3$ ' i.e.4 feet length 1.5 feet breadth and 3 feet depth 'Ksharasutra'cabinet was designed. 'Ksharasutra'cabinet used was facilitated with hot air fan and an ultra violet lamp for the maintenance of moisture free, dry air $\&$ sterilization $\left(40^{\circ} \mathrm{C}\right)$ purpose. After completions of 21 coatings, each thread measuring about 10-11 inches were cut away from the hangers and sealed in glass tube.

The standard 'Ksharsutra' was prepared by repeated 11 coatings of snuhi ksheera (latex of Euphorbia Nerrifolia), 7 coatings of 'Apamarg kshara' (ash of Achyranthus aspera) and 3 coatings of
'Haridra' powder over a surgical linen thread no. 20. This thread was spreaded throughout lengthwise in hangers [Fig-6]. Each thread on the hanger was then smeared with 'Snuhi' latex with the help of gauze piece soaked in the latex. This wet hanger is transferred in 'Ksharasutra' cabinet. The same process was repeated next day. Eleven such coatings with 'Snuhi ksheera' alone should be accomplished. The twelfth coating was done by first smearing the thread with 'Snuhi ksheera' and in wet condition thread is passed through the Apamarg kshara. It was again transferred into the cabinet for drying. This process was repeated till seven coatings of 'Snuhi ksheera' and 'Apamarg kshara' were achieved. The final three coatings were completed with 'Snuhi ksheera' and fine powder of 'Haridra' (turmeric) by passing hanger through the 'Haridra' powder. In this way twenty-one coatings over surgical linen thread no. 20.were achieved [18].

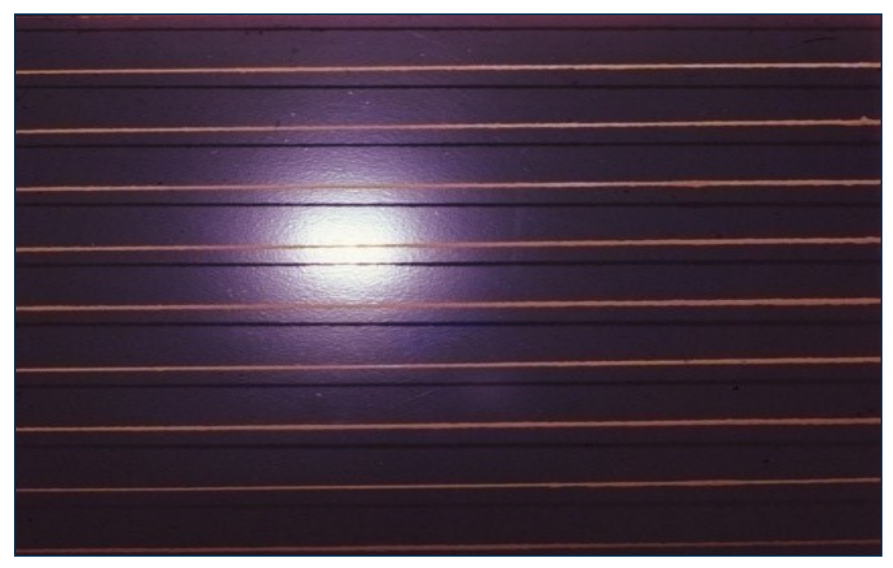

Fig. 6- Prepared Ksharsutra

\section{Mode of Action}

According to Ayurveda 'Ksharsutra' has action of Excision(Chedan), Scrapping(Lekhan), Draining(Vishtravan), Debridement(Shodhan), Healing(Ropan), Bactericidal and Bacteriostatic etc [19]. It can be suggested that due to the antimicrobial, antinflammatory action,\& Tridoshaghna and due to Visheshakriyaavacharanaat [4] it allows the proper drainage of pus from the unhealthy fistulous tract, that ultimately helps for proper wound healing. At The same time 'Ksharsutra' incises (cut) the Partial fistulous tract gradually without a conventional surgical incision and helps in wound healing. As 'Ksharsutra' having action like healing while cutting the partially left fistulous tract, it cuts and heals simultaneously.

\section{Observation and Results}

\section{A. Standardization of 'Ksharasutra'}

[Table-2] Showing Standardization of 'Ksharasutra'

Table 2- Standardization of 'Ksharasutra'

\begin{tabular}{|lll|}
\hline Sr. No & Test Parameters & Results \\
\hline 1 & Length & $15 \mathrm{~cm}$ \\
2 & Gauge of the Thread & $14 \mathrm{to} 16$. \\
3 & Tensile strength & $5 \mathrm{Kg}$. \\
4 & Diameter & $2.95 \mathrm{~mm}$ \\
5 & Total Weight & $1.8 \mathrm{gms}$ \\
6 & Water Soluble Extractive & $66.6 \% \mathrm{w} / \mathrm{w}$ \\
7 & pH & 9.8 \\
8 & Sodium & $5.98 \% \mathrm{w} / \mathrm{w}$ \\
9 & Potassium & $47.98 \% \mathrm{w} / \mathrm{w}$ \\
10 & Total Alkalis as Carbonate & $9.2 \% \mathrm{w} / \mathrm{w}$ \\
\hline
\end{tabular}




\section{B. Progressive Assessments of Parameters by Paired Stu- dent's 't' test}

The week wise progressive assessments of parameters by paired student's 't' test are shown in [Table-3]

Table 3- Progress of parameters in different stages of the treatment

\begin{tabular}{|c|c|c|c|c|c|c|c|c|c|}
\hline \multirow[b]{2}{*}{ Symptoms } & \multicolumn{3}{|c|}{ 1st Week } & \multicolumn{3}{|c|}{ 8th Week } & \multicolumn{3}{|c|}{ 12th Week } \\
\hline & Mean & $\begin{array}{c}\text { 't29' } \\
\text { Value }\end{array}$ & $\begin{array}{c}\mathrm{P}- \\
\text { Value }\end{array}$ & & $\begin{array}{c}\text { 't29' } \\
\text { Value }\end{array}$ & $\begin{array}{c}\mathrm{P}- \\
\text { Value }\end{array}$ & $\mathrm{Me}$ & $\begin{array}{l}\text { "t29" } \\
\text { Value }\end{array}$ & $\begin{array}{c}\text { P- } \\
\text { Value }\end{array}$ \\
\hline ain & 1.82 & 2.98 & $<0.01$ & 1.98 & 4.06 & $<0.001$ & 1.46 & 6.24 & $<0.001$ \\
\hline Discha & 1.36 & 2.06 & $<0.01$ & 2.06 & 3.51 & $<0.01$ & 1.86 & 6.68 & $<0.001$ \\
\hline Burnin & 1.78 & 2.24 & $<0.02$ & 1.96 & 3.4 & $<0.01$ & 1.94 & 7 & $<0.001$ \\
\hline Inting & 1.94 & 3.38 & $<0.01$ & 1.68 & 4.87 & $<0.01$ & 2.01 & 4.9 & $<0.001$ \\
\hline ize of wound & 1.78 & 3.4 & $<.0 .01$ & 2.46 & 6.84 & $<0.001$ & 1.89 & 7.2 & $<0.001$ \\
\hline
\end{tabular}

\section{Unit Cutting Time (UCT)}

UCT (Unit cutting time) - UCT $=\frac{\text { Totalno. of days taken to cut through }}{\text { Initial length of tract in cms }}=$ Days $/ \mathrm{Cms}$

There is several factors, which affect the Unit Cutting Time (UCT) as follows:

a. UCT is less in sub mucosal, subcutaneous.

b. UCT is high in cases of fibrosed/tough scar tissue which generally chronic anal fistula and in case of high rectal fistula and trans-sphincteric fistula.

c. Presence of infection and inflammation delays the UCT.

Length of Fistula: Since the measurement of unit cutting time depends on the initial length of fistula, it is very important to measure it. Various previous research works have reported that the length of 'Ksharsutra' initially applied will correspond to the length of the fistula though it indicates total circumference of the tract. Therefore, for all patients this length was considered as initial length of fistula. The initial lengths of fistulous tract after partial fistulectomy were varied from $3.5 \mathrm{~cm}$ to $16.0 \mathrm{~cm}$

Table 4- Progress of unit cutting time

\begin{tabular}{|lccccc} 
Sr. & Type & $\begin{array}{c}\text { Number of } \\
\text { Patients }\end{array}$ & $\begin{array}{c}\text { Average Length } \\
\text { of fistula }\end{array}$ & $\begin{array}{c}\text { Average Days } \\
\text { taken for cutting }\end{array}$ & $\begin{array}{c}\text { UCT } \\
\text { Nays/cm }\end{array}$ \\
\hline 1 & High anal fistula & 19 & $5 \mathrm{~cm}$ & 40 & 8 \\
2 & Horse Shoe fistula & 11 & $7 \mathrm{~cm}$ & 45 & 6.42 \\
Average UCT & & & & 7.21 \\
\hline
\end{tabular}

Average U.C.T. (Days/ cm) in overall patient was 7.21 Days $/ \mathrm{Cm}$ [Table-5] and also it was observed that in all cases fistula tract were simultaneously healed by 'ksahrsutra' therapy.

1. Ksharsutra' of $15 \mathrm{~cm}$ of $14-16$ gauge were standardized \& it was observed that it has tensile strength of $5 \mathrm{~kg}$, were as $\mathrm{Ph}$ was 9.8 [Table-2].

2. During the study it was observed that $21(70 \%)$ Patients were male and only $7(30 \%)$ patients were female.

3. $11(37 \%)$ patients were from Hindu religion, $15(50 \%)$ patients were from Muslim and 4(13\%) patients were Christian.

4. In this present series, $12(40 \%)$ patients were in the age group of 31-40 years whereas $9(30 \%)$ patients were in the age group 20-30years, $7(23 \%)$ patients were in the age group $41-50$ years, $2(7 \%)$ of Patients were in age group of above 51years.

5. In this study out of 30 randomly selected patients, $21(70 \%)$ of them had only one external opening while $5(17 \%)$ patients had 2 external openings and whereas another 4(13\%) patients had more than 2 openings. In this study 25(82\%) patients had posterior openings while $5(18 \%)$ of patients had anterior openings.
6. None of the patient showed any complications like frequent damage to the sphincter muscle resulting in incontinence of sphincter control, fecal soiling, rectal prolapse, anal stenosis, delayed wound healing and even after partial fistulectomy with 'ksharsutra' rate of recurrence was significantly reduced.

7. During the study only 1 patient $(3-4 \%)$ had recurrence, so recurrence rate was very minimum.

8. From over all therapeutic evaluation it was observed that by partial fistulectomy with 'ksharsutra' 22 patients of high anal/ horse shoe fistula significantly $(100 \%)$ cured in an average 9 weeks [Fig-7]. 8(27\%) patients were significantly improved within the observed period, because fistulous tract was more in length and some cases had multiple opening (horse shoe anal fistula) so they took more duration for complete cure.

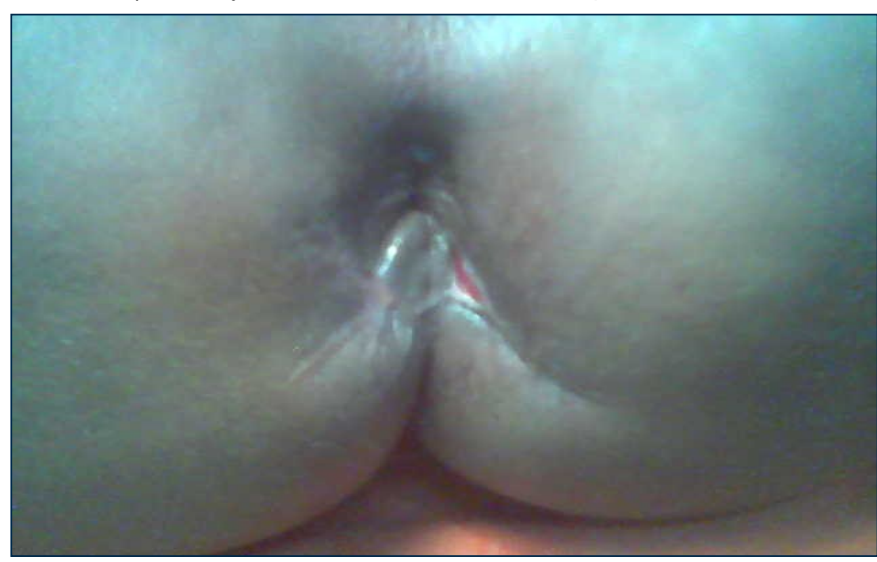

Fig. 7- After complete cure (8th week)

\section{Discussion}

The management of anal fistula in an effective manner has always been a challenge to the surgeons world over. The conventional operative treatment of anal fistula is to lay open or completely excise the fistulous track and allow healing by open granulation [5]. In high anal fistula, complete excision is not possible and the operative procedure has had to be modified to consist of partial excision along with the use of a 'Ksharsutra' to achieve radical cure.

Anal fistula is known to be predominantly a disease of middle-aged (31-40Yrs) men. From the study it was also observed that high anal/ horse shoe fistula is common amongst Muslim religion (40\%), where as very commonly seen in lower socioeconomic group people.

During the evaluation of parameters symptom pain was progressively decreased significantly, when the patient reported that he has no pain that day was noted and it was considered as the pain relief day (PRD). Average Pain relief day was 4 days, whereas pain was moderate during the first 2 days of post partial fistulectomy with 'ksharsutra'. After completion of study pain was significantly decreased with 't' Value- 6.24,P<0.01 [Table-3].

Pus discharge in the case of high anal /horse shoe fistula is major factor which brings patient to surgeon where as partial fistulectomy with 'ksharsutra' allows pus to drained out so the chances of cavity development is reduced and simultaneously pus is drained out and along with that as 'kshar' also have Antimicrobial, Tridoshaghna and due to Visheshakriyaavacharanaat [4] activity because of that it also decreases the infection load. In this study it was observed that pus discharge significantly decreases with ' $\mathrm{t}$ ' value $6.68 \mathrm{P}<0.01$ [Table-3]. 
Burning sensation and itching in anal region is a common symptom seen in case of fistula even after application of 'ksharsutra' but it was significantly decreased with 't' Value- $7.0, P<0.01$ \& 't' Value$4.9, \mathrm{P}<0.01$ [Table-3] respectively.

As compaired with total fistulectomy, partial fistulectomy with'ksharsutra' has a small size of wound and as 'ksharsutra' also has anti inflammatory, antimicrobial \& Tridoshaghna and due to Visheshakriyaavacharanaat [17] action wound heal ('t'Value-7.2, $P<0.01)$ [Table-3] without major complication like delayed wound healing, Abscess cavity development etc.

As fistulous tract were cut down with UCT-7.21 days/cm and none of the patients showed delayed healing, so in all fistulous tract cutting and healing occurs simultaneously.

It does not require hospitalization for prolonged duration and patients could continue with their normal routine work, thus patient's social, psychological and economic status is not disturbed during the treatment.

Impaired continence is transient and related to the stage of 'cutting through' the anal sphincters by the 'ksharsutra', which subsequently recovers during the course of follow-up.

As mentioned in 'Sushrut Samhita' chikitsa adjuvant therapy like hot sitz bath improves blood circulation and helps in wound healing where as good for maintaining local hygiene [4]. Haritaki improves digestion, promotes the absorption of nutrients, and regulates colon function [20].

The rate of recurrence after the treatment is negligible as compared to its various other seton and surgical management.

No systemic side effects was encountered with 'ksharsutra' therapy, although transient infection, local burning sensation, mild pain, itching and slight indurations was observed, which rarely need medication.

Post-operative tissue damage and scarring were minimal. The 'ksharsutra' therapy, a unique method of drug delivery, most appropriate for healing the fistulous track offers an successful, daycare base and safe ancient alternative treatment in patients with anal fistula.

\section{Conclusion}

On the basis of findings and observations obtained after completion of current work it can be concluded that partial fistulectomy with 'Ksharsutra' in anal fistula (high anal/horse shoe) is an effective treatment with minimal \& minor complication, cure rate is very high with less degree of recurrence. Treatment with this modality minimizes post-operative complications, like damage to the sphincter muscle resulting in incontinence of sphincter control, fecal soiling, rectal prolapse, anal stenosis, delayed wound healing, bleeding. Since it shortens hospital stay of patient due to fast recovery, it prevents hospital acquired infections and minimizes financial burden hence we can also conclude that this treatment is economical \& alternative for conventional surgery. As the sample size was too small, it is recommended to study large sample size with multicentric analysis to achieve concrete conclusion.

\section{Acknowledgement}

I express my deep gratitude towards my colleagues who helped me directly or indirectly for completing this research work. I am thankful to our dean Dr Bhaldikar for motivation \& management of Padamashree Dr D.Y. Patil University for giving me an opportunity to serve the community. Last but not least I am thankful to medical staff, paramedical staff and patients attending to Shalyatantra department without them I may not conclude this work.

\section{References}

[1] Vaidya Jadavaji Trikamji Acharya and Narayan Ram Acharya (2008) Sushruta, Sushruta samhita, Sutra Sthana, Avaraneeya Adhyaya, 33/4, 1st ed., Chowkhambha Surabharati Prakashan, Varanasi, 236.

[2] Shukla N.K., Narang R., Nair N.G., Radhakrishna S., Satyavati G.V. (1991) Indian J. Med. Res., 94, 177-85.

[3] Sainio P. (1984) Ann. Chir. Gynaecol., 73(4), 219-24.

[4] Vaidya Jadavaji Trikamji Acharya and Narayan Ram Acharya (2008) Sushruta, Nidana Sthana, Bhagandara Nidana Adhyaya, 1st ed., Chowkhambha Surabharati Prakashan, 280.

[5] Das S. (2007) A Practical Guide to Operative Surgery, 5th ed., Das Publications, 400-19.

[6] Buchanan G.N., Bartram C.I., Phillips R.K. (2003) Dis Colon Rectum., 46(9), 1167-74.

[7] Loungnarath R., Dietz D.W., Mutch M.G., Birnbaum E.H., Kodner I.J., Fleshman J.W. (2004) Dis. Colon. Rectum., 47(4), 432-6.

[8] Shafik A. (1993) J. Clin. Gastroenterol., 16(4), 304-8.

[9] Misra T.N., Singh R.S., Pandey H.S., Prasad C., Singh B.P. (1992) Phytochemistry, 31, 1811-1812.

[10]Sushil K., Bagchi G.D, Darokar M.P. (1997) Int. J. Pharmacog., 35, 179-184.

[11]Neogi N.C., Garg R.D., Rathor R.S. (1970) Indian J. Pharm., $32,43-46$.

[12]Sutar N.G., Sutar U.N., Sharma Y.P., Shaikh I.K. and Kshirsagar S.S. (2008) Biosciences Biotechnology Research Asia, 5 (2), 841-844.

[13]Rasik A.M., Shukla A., Patnaik B.N., Dhawan D.K., Srivastava K.S. (1996) Indian Journal of Pharmacology, 28, 107-109.

[14]Bhavani Shankar T.N., Sreenivasa Murthy V. (1979) Indian J. Exp. Biol., 17(12), 1363-6.

[15]Chandra D., Gupta S.S. (1972) Indian Journal of Medical Research, 60, 138-142.

[16]Kuo M.L., Huang T.S. and Lin J.K. (1996) Biochim. Biophys. Acta., 1317, 95-100.

[17]Lutomski J., Kedzia B., Debska W. (1974) Planta. Med., 26, 919.

[18]Sharma P.V., Chakradatta (2002) Arsha Chikitsa, 87 Chukamba Publication, Varanasi.

[19]Sharma S.K., Sharma K.R., Singh K. (1995) KsharaSutra Therapy in Fistula-in-ano and other Ano-Rectal Disorders, R.A.V. Publication, New Delhi.

[20]SuryaPrakash D.V., Sree Satya N., Sumanjali Avanigadda and Meena Vangalapati (2012) International Journal of Research in Pharmaceutical and Biomedical Sciences, 3(2), 679-683. 